\title{
Over- and under-expressed microRNAs in human colorectal cancer
}

\author{
KAZUO MOTOYAMA $^{1,2}$, HIROSHI INOUE $^{1}$, YASUSHI TAKATSUNO ${ }^{1,2}$, FUMIAKI TANAKA $^{1}$, \\ KOSHI MIMORI ${ }^{1}$, HIROYUKI UETAKE $^{2}$, KENICHI SUGIHARA $^{2}$ and MASAKI MORI ${ }^{1,3}$

\begin{abstract}
${ }^{1}$ Department of Molecular and Surgical Oncology, Medical Institute of Bioregulation, Kyushu University, 4546 Tsurumibaru, Beppu 874-0838; ${ }^{2}$ Department of Surgical Oncology, Graduate School of Medical and Dental Science, Tokyo Medical and Dental University, 1-5-45 Yushima, Bunkyo-ku, Tokyo 113-8519; ${ }^{3}$ Department of Gastroenterological Surgery,

Graduate School of Medicine, Osaka University, 1-1, Yamadaoka, Suita 565-0871, Japan
\end{abstract}

Received October 22, 2008; Accepted December 18, 2008

DOI: 10.3892/ijo_00000233

\begin{abstract}
MicroRNAs (miRNAs) constitute a class of small (21-23 nucleotides) noncoding RNAs that function as posttranscriptional gene regulators. It is becoming increasingly clear that altered miRNA expression correlates with the pathogenesis of cancers. The purpose of this study was to determine the up-regulated miRNAs in human colorectal cancer. Total RNA was isolated from cancer tissues and corresponding noncancerous tissues from surgically resected colorectal cancers. The expression profiles of miRNAs were determined using a miRNA microarray containing 455 human miRNA probes. The expression status of selected miRNAs in paired clinical samples was then investigated by real-time RT-PCR. Twenty-one miRNAs were identified by miRNA array analysis as overexpressed in colorectal cancer tissues compared to normal epithelial tissues. Among them, the expression of $m i R-31, m i R-183, m i R-17-5 p, m i R-18 a, m i R-20 a$ and $m i R-92$ were confirmed to be significantly higher in cancer tissues than in normal tissues $(\mathrm{P}<0.05)$. In contrast, the expression of $m i R-143$ and $m i R-145$ in cancer tissues were significantly lower than in normal tissues $(\mathrm{P}<0.05)$. The $m i R-18 a$ overexpression group tended to have a poorer clinical prognosis than the low expression group $(\mathrm{P}=0.07)$. We identified miRNAs that were overexpressed or underexpressed in colorectal cancers and which may be correlated with colorectal carcinogenesis.
\end{abstract}

\section{Introduction}

MicroRNAs (miRNAs) are evolutionarily-conserved, endogenous, small, noncoding RNA molecules of $\sim 21-23$

Correspondence to: Professor Masaki Mori, Department of Gastroenterological Surgery, Graduate School of Medicine, Osaka University, 1-1, Yamadaoka, Suita 565-0871, Japan

E-mail: mmori@gesurg.med.osaka-u.ac.jp

Key words: microRNA, human colorectal cancer, microRNA microarray nucleotides that function as post-transcriptional gene regulators (1-4). Mature miRNAs are integrated into a ribonucleoprotein complex called the RNA-inducing silencing complex (RISC) and associate with 3' untranslated regions (3'UTRs) of specific target messenger RNAs (mRNAs) to suppress translation and also to occasionally induce mRNA decay (5-9). It is estimated that vertebrate genomes encode up to 1,000 unique miRNAs, each of which is thought to regulate the expression level of a target gene (10). Up to $30 \%$ of human genes are thought to be regulated by miRNAs; however, most of the targets remain unknown (11). Recent evidence has shown that miRNAs are involved in regulation of cellular development, differentiation, proliferation and apoptosis (12).

More than 500 miRNAs have been identified in humans and more than half of human miRNAs are located at specific chromosomal regions, including fragile sites, as well as in regions that are frequently amplified, deleted, or rearranged in cancers $(13,14)$. Recent evidence has shown that altered expression of miRNAs is associated with the pathogenesis of various human cancers and has indicated that some miRNAs may function as oncogenes or tumor suppressors (15-20). A number of studies were recently published that focus on the significance of miRNAs in colorectal cancer (21-26). Although assays such as Northern blots and real-time RT-PCR are important in understanding the expression status of individual miRNAs, comprehensive microarray analysis using clinical samples is needed to elucidate the clinical significance of miRNAs in colorectal cancer.

In this study, a microRNA microarray containing 455 human miRNA probes was used to determine expression profiles in colorectal cancer tissue and 21 up-regulated colorectal cancer-related miRNAs were identified. Expression of $m i R-31$ in cancers was significantly higher than in normal tissues on 69 clinical colorectal cancers by real-time RT-PCR, suggesting that $m i R-31$ may be one of the potent colorectal cancer-related miRNAs. The MiR-17-92 cluster may also play an important role in colorectal cancer progression. Furthermore, we demonstrate that $m i R-18 a$ expression could be used as a prognostic factor in predicting survival of colorectal cancer patients. 


\section{Materials and methods}

Patients and clinical samples. Samples of cancerous tissue and matched noncancerous tissues were obtained from 69 patients with colorectal cancer who underwent surgical resection at Kyushu University Hospital (Beppu, Japan). None of the patients received preoperative treatments, such as radiation and/or chemotherapy. The follow-up periods ranged from 0.1 to 11.3 years with a mean of 3.7 years. Written informed consent was obtained from all patients according to the guidelines approved by the Institutional Research Board and this study was conducted under the supervision of the ethical board of Kyushu University.

The 69 tumor samples and the matched control samples taken from normal tissue located at a distance from the colorectal cancer were frozen in liquid nitrogen immediately after surgical resection and were stored at $-90^{\circ} \mathrm{C}$ until RNA extraction.

MicroRNA microarray analysis. Total RNAs from tumor and the matched control samples of 4 of 69 cases were analyzed by microRNA microarray. Total RNA was extracted from tissue using TRIzol reagent (Invitrogen) according to the manufacturer's protocol. Concentration and purity of the total RNAs were assessed by a spectrophotometer and RNA integrity was verified using an Agilent 2100 bioanalyzer (Agilent Technologies).

Total RNA (100 ng) was directly labeled with cyanine 3-CTP (Cy3), without fractionation or amplification, using an Agilent protocol that produces precise and accurate measurements spanning a linear dynamic range from 0.2 amol to 2 fmol of input miRNA. Each (100 ng) of 4 total RNAs from cancer tissue samples and a mixture of total RNAs (100 ng) extracted from normal epithelial tissues were competitively hybridized to a miRNA array (Agilent Microarray Design ID $=014947$, Early Access version) containing 455 miRNAs, according to the manufacturer's protocol (27). A list of miRNAs contained in the array is available from version 8.2 of the Sanger miRNA database (http://microrna.sanger.ac.uk).

Data analysis. The intensity of each hybridization signal was evaluated using Feature extraction Software (Agilent Technologies). Feature Extraction analysis examines multiple probes and multiple features per probe and studies the measurements and errors for each miRNA. The observed values were imported into GeneSpring GX version 7.3 (Agilent Technologies). Generated miRNA profiles were normalized to the amount of input total RNA. A miRNA was designated overexpressed if expression was $>2.6$-fold compared to normal epithelial rectal tissues in all 4 clinical colorectal cancer samples (Table I).

MiRNA real-time RT-PCR. MiR-31-, miR-183-, miR-17-5p-, miR-18a, miR-20a-, miR-92- and RNU6B (internal control)specific cDNAs were synthesized from total RNAs extracted from a maximum of 69 paired clinical samples using genespecific primers according to TaqMan MicroRNA assays (Applied Biosystems). Reverse transcriptase reactions contained $10 \mathrm{ng}$ of total RNA, $50 \mathrm{nM}$ stem-loop RT primer,
Table I. Clinicopathological data in 4 colorectal cancers for microRNA microarray.

\begin{tabular}{lcccc}
\hline Case & 1 & 2 & 3 & 4 \\
\hline Age & 42 & 65 & 68 & 67 \\
Gender & Female & Male & Male & Female \\
Tumor size (cm) & $3.5 \times 3.5$ & $4.1 \times 3.5$ & $2.5 \times 2.5$ & $3.5 \times 2.5$ \\
Location & S & Rb & S & S \\
Histological type & Well & Well & Well & Well \\
Lymph node metastasis & $(+)$ & $(+)$ & $(-)$ & $(-)$ \\
Lymphatic invasion & $(+)$ & $(-)$ & $(-)$ & $(-)$ \\
Venous invasion & $(+)$ & $(+)$ & $(-)$ & $(-)$ \\
Depth & se & se & sm & ss \\
Peritoneal dissemination & $(-)$ & $(-)$ & $(-)$ & $(-)$ \\
Liver metastasis & $(-)$ & $(-)$ & $(-)$ & $(-)$ \\
Stage & IIIa & IIIa & I & II \\
Outcome & Alive & Death & Alive & Alive \\
\hline
\end{tabular}

$\mathrm{S}$, sigmoid colon; Rb, rectum (below the peritoneal reflection); well, well-differentiated adenocarcinoma; sm, submucosa; ss, subserosa and se, serosa.

1X RT buffer, $0.25 \mathrm{mM}$ each of dNTPs, $3.33 \mathrm{U} / \mu 1$ MultiScribe reverse transcriptase and $0.25 \mathrm{U} / \mu 1 \mathrm{RNase}$ Inhibitor. The $7.5 \mu 1$ reaction volumes were incubated in a 96-well plate in a Bio-Rad iCycler (Bio-Rad Laboratories) for $30 \mathrm{~min}$ at $16^{\circ} \mathrm{C}, 30 \mathrm{~min}$ at $42^{\circ} \mathrm{C}, 5 \mathrm{~min}$ at $85^{\circ} \mathrm{C}$ and were then held at $4^{\circ} \mathrm{C}$.

Real-time PCR was performed using an Applied Biosystems 7500 real-time PCR system. Each $10 \mu 1$ PCR volume included $0.67 \mu 1 \mathrm{RT}$ products, $1 \mathrm{X}$ TaqMan Universal PCR master mix and $1 \mu \mathrm{l}$ of primers and probe mix from each TaqMan microRNA assay. The reactions were incubated in 96 -well optical plates at $95^{\circ} \mathrm{C}$ for $10 \mathrm{~min}$, followed by 45 cycles of $95^{\circ} \mathrm{C}$ for $15 \mathrm{sec}$ and $60^{\circ} \mathrm{C}$ for $10 \mathrm{~min}$. The relative expression of each miRNA was calculated using the $2^{-\Delta \Delta C t}$ method, with the ratio of the median expression sample among all tumor samples/all non-tumor samples being used as the calibrator. The expression level of each miRNA was normalized to $R N U 6 B$ expression.

Statistical analysis. Biostatistical analyses were performed with JMP 5.0.1a for Windows software (SAS Institute). Possible differences between groups were analyzed using the Student's t-test. Survival curves were obtained by the KaplanMeier method (28); comparison between curves was made by log-rank test. A probability level of 0.05 was chosen for statistical significance.

\section{Results}

Identification using miRNA array analysis of miRNAs that are overexpressed in clinical colorectal cancer. To investigate the differential expression of miRNAs in human colorectal cancers, array-based miRNA profiling of human colorectal 
Table II. Twenty-one miRNAs up-regulated in clinical human colorectal cancers by miRNA array analysis. ${ }^{a}$

\begin{tabular}{|c|c|c|}
\hline MicroRNA & Cases & Fold change \\
\hline hsa-miR-31 & $4 / 4$ & 179.29 \\
\hline hsa-miR-18b & $4 / 4$ & 175.71 \\
\hline$h s a-m i R-30 e-3 p$ & $4 / 4$ & 71.82 \\
\hline hsa-miR-220 & $4 / 4$ & 51.05 \\
\hline$h s a-m i R-570$ & $4 / 4$ & 35.25 \\
\hline$h s a-m i R-302 b$ & $4 / 4$ & 31.51 \\
\hline hsa-miR-302a & $4 / 4$ & 27.81 \\
\hline hsa-miR-183 & $4 / 4$ & 18.94 \\
\hline hsa-miR-224 & $4 / 4$ & 14.46 \\
\hline$h s a-m i R-18 a$ & $4 / 4$ & 10.49 \\
\hline hsa-miR-95 & $4 / 4$ & 10.13 \\
\hline hsa-miR-7 & $4 / 4$ & 7.96 \\
\hline hsa-miR-182 & $4 / 4$ & 5.63 \\
\hline$h s a-m i R-17-5 p$ & $4 / 4$ & 4.83 \\
\hline hsa-miR-550 & $4 / 4$ & 4.74 \\
\hline hsa-miR-196b & $4 / 4$ & 4.61 \\
\hline hsa-miR-181d & $4 / 4$ & 4.42 \\
\hline hsa-miR-20a & $4 / 4$ & 4.38 \\
\hline hsa-miR-92 & $4 / 4$ & 4.14 \\
\hline hsa-miR-493-3p & $4 / 4$ & 4.07 \\
\hline hsa-miR-29a & $4 / 4$ & 3.75 \\
\hline
\end{tabular}

${ }^{a}$ Fold change of miRNA expression was calculated relative to normal colorectal epithelial tissues. The bolded miRNAs signify those that were analysed by real-time RT-PCR. cancer was performed. Out of 455 human miRNAs assayed, 21 were identified that had higher expression levels in colorectal cancer tissues than in normal epithelial tissues (Table II). MiR-31 was the most up-regulated miRNA in the colorectal cancer tissues analyzed. Among the up-regulated miRNAs, $m i R-17-5 p, m i R-18 a, m i R-20 a$ and $m i R-92$ are included in the $m i R-17-92$ cluster.

Real-time RT-PCR analysis of mature miRNAs. A maximum of 69 paired clinical samples were analyzed by real-time RT-PCR to quantify the expression of six up-regulated miRNAs $(m i R-31, m i R-183, m i R-17-5 p, m i R-18 a, m i R-20 a$ and $m i R-92)$. The mean expression levels of $m i R-31, m i R-183$, miR-17-5p, miR-18a, miR-20a and miR-92 were higher in tumor than in non-tumor tissues $(\mathrm{P}<0.05$, Fig. 1$)$. The percentages of cases in which the expression levels of $m i R-31$, miR-183, miR-17-5p, miR-18a, miR-20a and miR-92 were higher in tumor than in non-tumor tissues, were 63.8, 83.9, 71.6, 76.9, 77.6 and 66.7\%, respectively (Table III).

We then investigated the expression levels of $m i R-143$ and miR-145, which were reported as down-regulated miRNAs in colorectal cancer $(21,22,25,29)$. The mean expression levels of $m i R-143$ and $m i R-145$ were lower in tumor than in non-tumor tissues $(\mathrm{P}<0.05$, Fig. 2). The percentages of cases in which the expression levels of $m i R-143$ and $m i R-145$ were lower in tumor than in non-tumor tissues, were 72.1 and $68.2 \%$, respectively (Table III).

High miR-18a expression correlates with poor prognosis. We next surveyed the relationship between the expression of $m i R-18 a$ and prognosis in colorectal cancer patients. Based upon the mean expression level of $m i R-18 a, 65$ clinical cases were divided into two groups: high $m i R-18 a$ expression $(\mathrm{n}=21)$ and low $m i R-18 a$ expression $(\mathrm{n}=44)$. The $m i R-18 a$ overexpression group tended to have a poorer clinical prognosis than the low expression group ( $\mathrm{P}=0.07$; Fig. 3 ).

Table III. The expression level of up-regulated and down-regulated miRNAs were surveyed on paired clinical samples of colorectal cancer by real-time RT-PCR.

\begin{tabular}{|c|c|c|c|c|c|c|}
\hline Up-regulated miRNAs & $m i R-31$ & $m i R-183$ & $m i R-17-5 p$ & $m i R-18 a$ & $m i R-20 a$ & $m i R-92$ \\
\hline $\begin{array}{l}\text { Up-regulated/all cases } \\
(\%)\end{array}$ & $\begin{array}{l}44 / 69 \\
(63.8)\end{array}$ & $\begin{array}{l}52 / 62 \\
(83.9)\end{array}$ & $\begin{array}{l}48 / 67 \\
(71.6)\end{array}$ & $\begin{array}{l}50 / 65 \\
(76.9)\end{array}$ & $\begin{array}{l}52 / 67 \\
(77.6)\end{array}$ & $\begin{array}{l}46 / 69 \\
(66.7)\end{array}$ \\
\hline $\begin{array}{l}\text { Mean expression level in tumor } \\
(\text { mean } \pm \mathrm{SD})\end{array}$ & $3.80 \pm 8.50$ & $2.08 \pm 2.92$ & $2.34 \pm 3.12$ & $1.97 \pm 3.08$ & $1.38 \pm 1.59$ & $1.84 \pm 2.07$ \\
\hline $\begin{array}{l}\text { Mean expression level in non-tumor } \\
(\text { mean } \pm \text { SD) }\end{array}$ & $0.70 \pm 0.8$ & $0.39 \pm 0.38$ & $1.01 \pm 1.27$ & $0.86 \pm 1.23$ & $0.48 \pm 0.55$ & $1.03 \pm 0.83$ \\
\hline Down-regulated miRNAs & $\operatorname{miR}-143$ & $m i R-145$ & & & & \\
\hline $\begin{array}{l}\text { Down-regulated/all cases } \\
(\%)\end{array}$ & $\begin{array}{l}31 / 43 \\
(72.1)\end{array}$ & $\begin{array}{l}30 / 44 \\
(68.2)\end{array}$ & & & & \\
\hline $\begin{array}{l}\text { Mean expression level in tumor } \\
(\text { mean } \pm \text { SD) }\end{array}$ & $0.87 \pm 1.06$ & $0.96 \pm 1.30$ & & & & \\
\hline $\begin{array}{l}\text { Mean expression level in non-tumor } \\
(\text { mean } \pm \text { SD) }\end{array}$ & $1.58 \pm 1.74$ & $1.70 \pm 1.75$ & & & & \\
\hline
\end{tabular}



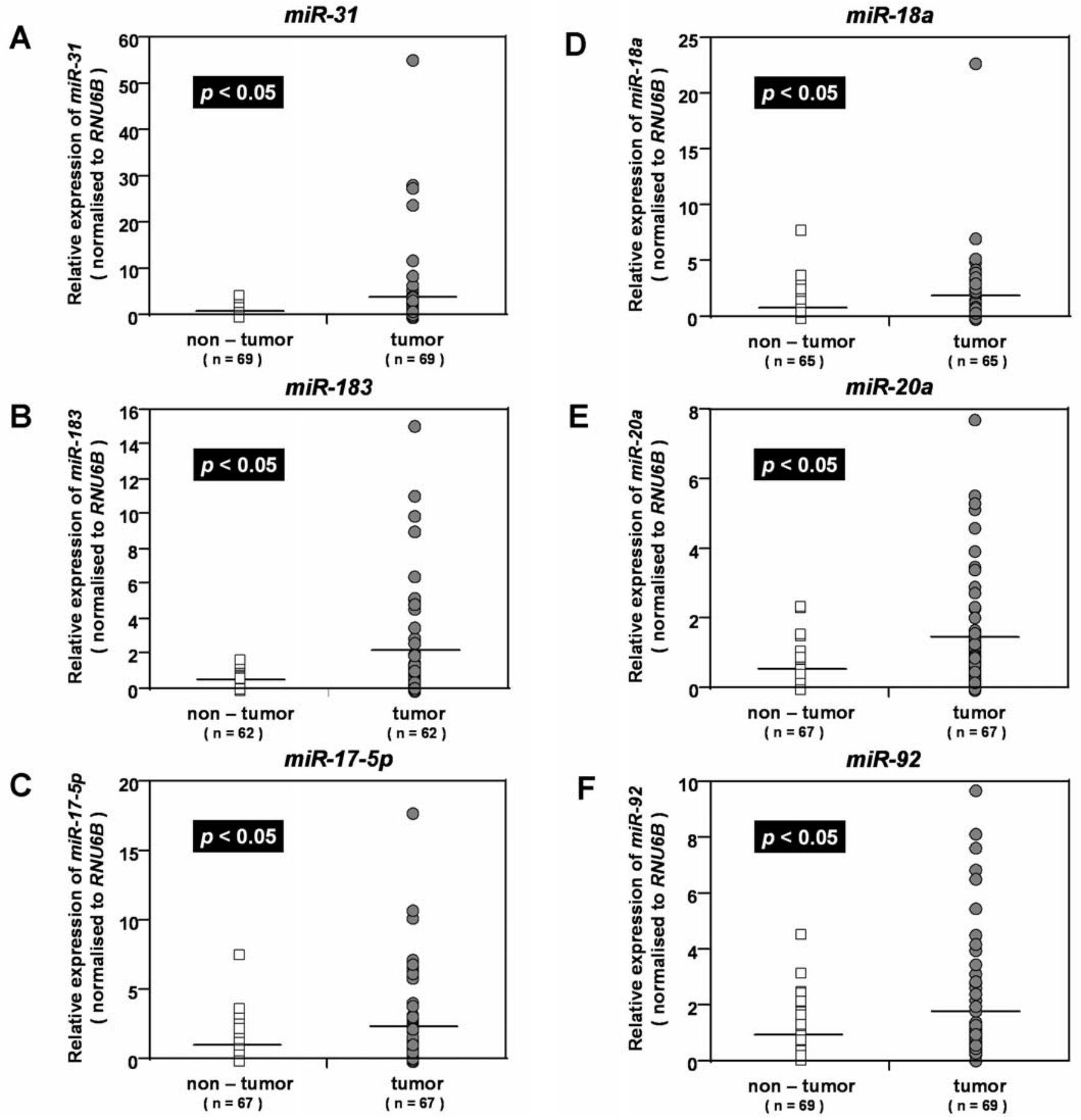

Figure 1. Part 1.

\section{Discussion}

Because of the large amount of evidence indicating that miRNAs are involved in carcinogenesis (15-20), it is important to identify colorectal cancer-related miRNA profiles by comprehensive analysis to increase understanding of colorectal cancer biology. In this study, a miRNA array with 455 known human miRNAs was applied to clinical samples of colorectal cancers to identify cancer-associated miRNAs. As a result, 21 cancer-related miRNAs were identified that were overexpressed in colorectal cancer tissues compared to normal colorectal epithelial tissues (Table II).
MiRNA expression profiling demonstrated that $m i R-31$ expression was the highest among the 21 overexpressed miRNAs seen in the colorectal cancer samples that were assayed (Table II). In addition, real-time RT-PCR analysis of 69 clinical colorectal cancers showed that $m i R-31$ expression was significantly higher in cancer than in normal tissues (Fig. 1A and a). Bandres et al surveyed the expression of 156 mature miRNAs in 16 colorectal cancer cell lines and 12 matched pairs of tumor and non-tumor tissues by realtime PCR and reported that $m i R-31$ was one of the seven overexpressed miRNAs and was associated with tumor stages of colorectal cancer (24). Slaby et al reported that the 
a

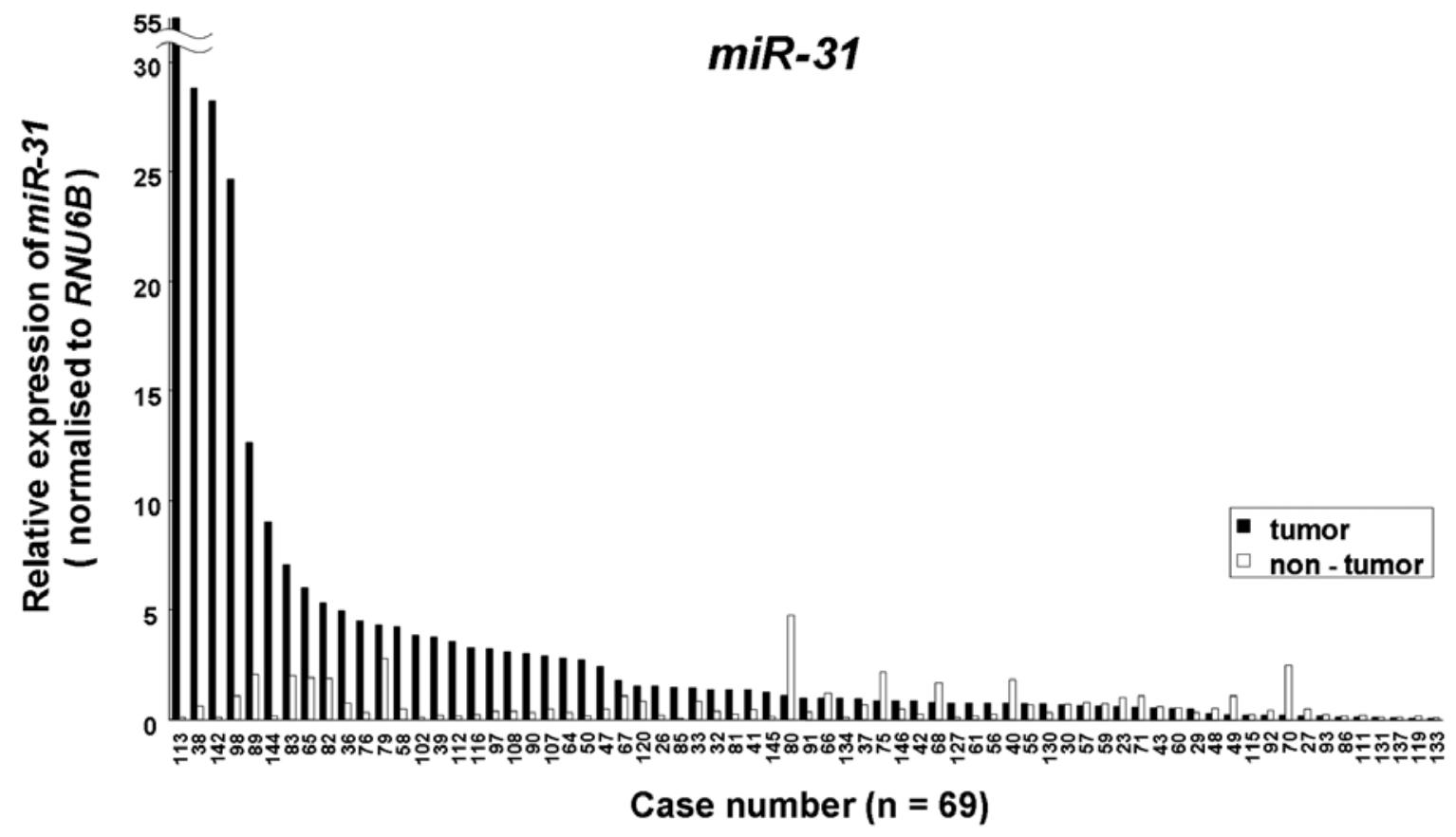

e

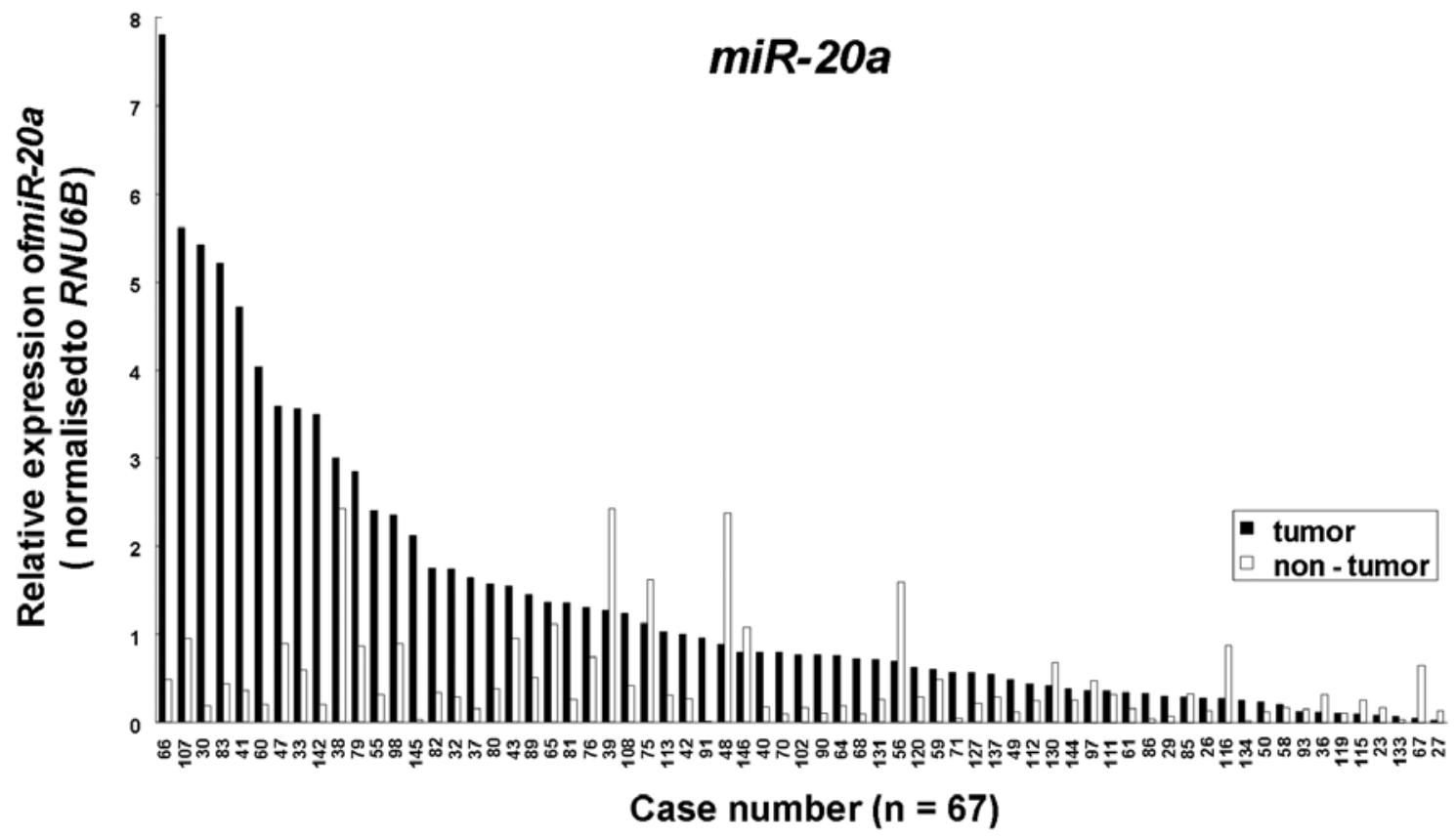

Figure 1. Part 2. Real-time RT-PCR analysis of 6 up-regulated miRNAs in tumor and non-tumor samples from colorectal cancer cases. Expression values of miRNAs were shown as the expression ratio of each miRNA to RNU6B. (A, a) miR-31 expression; (B) miR-183 expression; (C) miR-17-5p expression; (D) $m i R-18 a$ expression; (E, e) miR-20a expression; (F) miR-92 expression. Horizontal lines indicate the mean values of tumor and non-tumor samples.

expression of $m i R-31$ was up-regulated in 29 primary colorectal cancers (29). These studies suggest that $m i R-31$ is one of the important colorectal cancer-related miRNAs. Up-regulated miRNAs listed by Bandres et al included $m i R-183$ and $m i R-20 a$, which is consistent with our data that $m i R-183$ and $m i R-20 a$ were overexpressed in our colorectal cancer samples by both miRNA array and real-time RT-PCR analysis (Table II, Fig. 1B, E and e).

We demonstrated that expression of miR-17-5p, miR-18a, $m i R-20 a$ and $m i R-92$, which are cleavage products of the
miR-17-92 cluster, were individually up-regulated in our miRNA expression profiles and that by real-time RT-PCR analysis, their expression in clinical sample cancer tissues were also significantly higher than in normal tissues (Table II, Fig. 1C-F). The miR-17-92 cluster is comprised of 6 miRNAs (miR-17-5p, miR-18a, miR-19a, miR-19b-1, miR-20a and $m i R-92)(30)$. The $m i R-17-92$ cluster is overexpressed in malignant lymphoma cell lines and lung cancers $(31,32)$ and cooperates with c-MYC to accelerate tumor development (31). The introduction of miR-17-92 can enhance the growth 
A

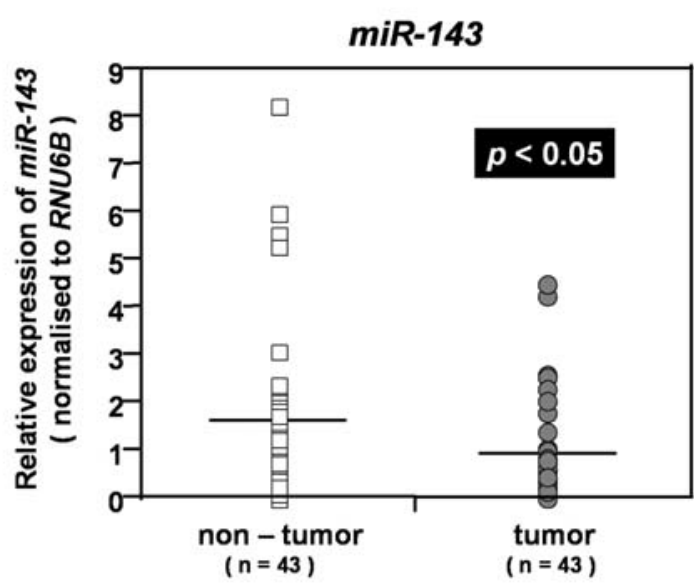

B

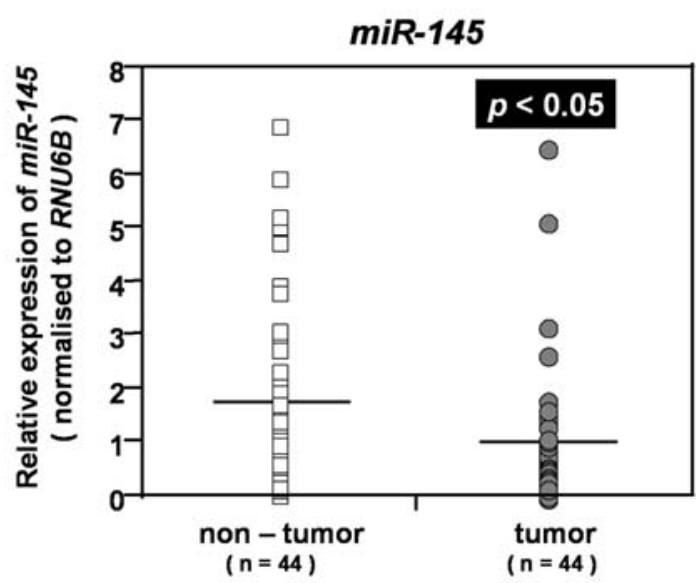

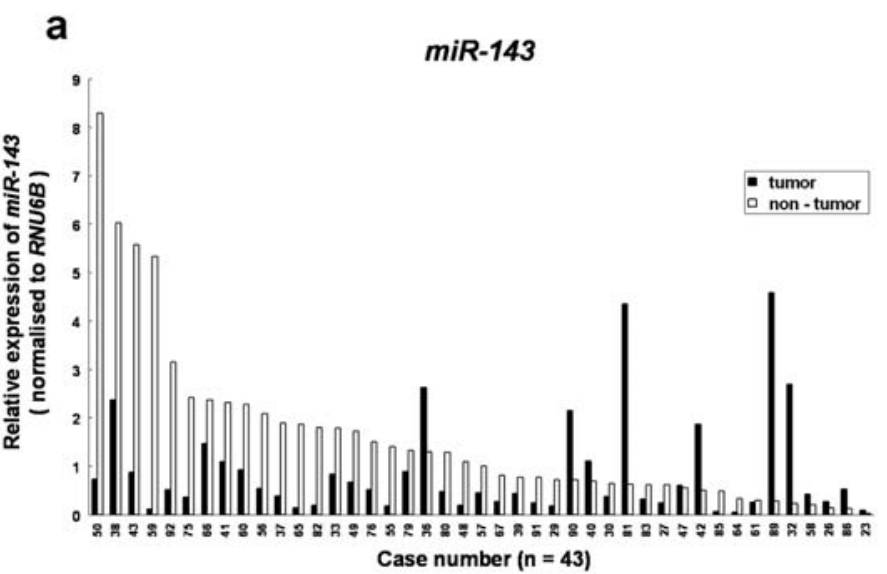

b $\quad \operatorname{miR}-145$

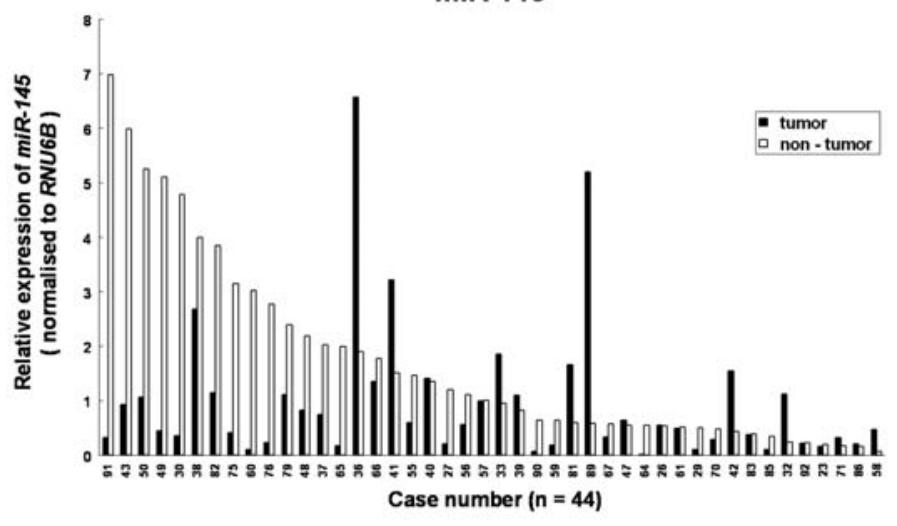

Figure 2. Real-time RT-PCR analysis of 2 down-regulated miRNAs in tumor and non-tumor samples from colorectal cancer cases. (A, a) miR-143 expression; $(\mathrm{B}, \mathrm{b}) \mathrm{miR}-145$ expression. Horizontal lines indicate the mean values of tumor and non-tumor samples.

miR-18a Overall survival

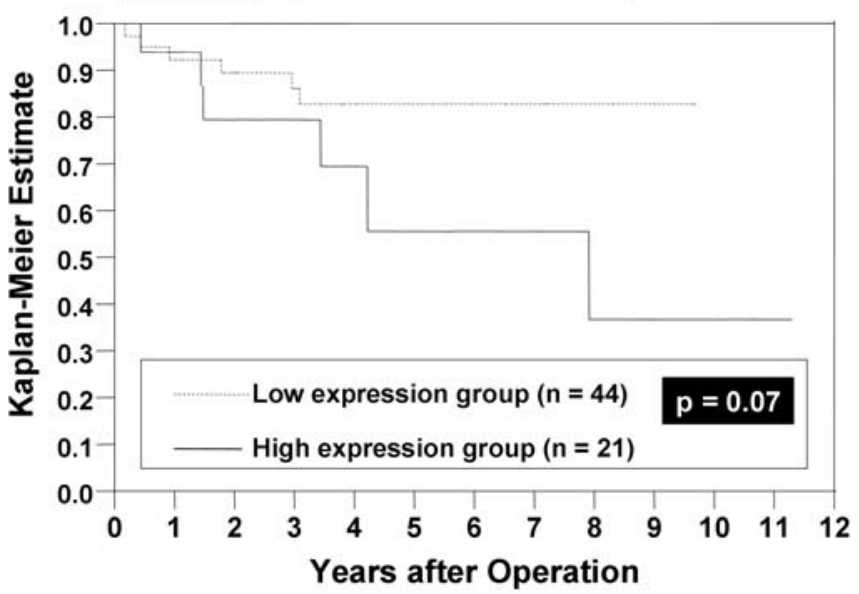

Figure 3. Survival curves of colorectal cancer patients according to $m i R-18 a$ expression status. High expression group $(\mathrm{n}=21)$ : $m i R-18 a>$ mean value; low expression group $(\mathrm{n}=44): m i R-18 a<$ mean value. By the log-rank test, patients with high $m i R-18 a$ expression tended to have poorer prognoses than those with low miR-18a expression $(\mathrm{P}=0.07)$.

property of lung cancer cells in vitro (32). Additional evidence indicates that $m i R-17-92$ can be a tumor angiogenesis mediator (33) and affects the expression of the members of the E2F family of oncogenic transcription factors (34-36). These studies suggest that the miR-17-92 polycistron may be the most prominent oncogenic miRNA cluster. Most recently, Ventura et al reported a link between the oncogenic properties of miR-17-92 and its functions during B cell lymphopoiesis and lung development (37).

In clinical colorectal cancers, He et al reported that the level of miR-17-92 pri-miRNA was up-regulated in $15 \%$ of tested samples and showed $>5$-fold up-regulation compared to corresponding normal tissues by real-time quantitative PCR (31). In this study, the percentages of cases with $>5$-fold expression levels of $m i R-17-5 p, m i R-18 a, m i R-20 a$ and $m i R-92$ in clinical colorectal cancer tissues were 29.2, 19.4, 31.3 and $11.6 \%$, respectively. Volinia et al, using prediction analysis of microarrays (PAM), reported that 21 miRNAs were overexpressed in 46 colorectal cancer samples compared to 8 normal colorectal tissues (23) and that elevated expression levels of $m i R-17-5 p$ and $m i R-20 a$ were found by miRNA expression profiling. Schetter et al reported that 27 miRNAs were overexpressed in miRNA array expression profiling of 84 colorectal tumor and paired non-tumorous tissues, which included miR-17-5p, miR-20a and miR-92 (26). Matsubara et $a l$ showed that inhibition of $m i R-17-5 p$ and $m i R-20 a$ expression by antisense oligonucleotides could selectively induce apoptosis in lung cancer cells that overexpressed $m i R$ 17-92 (38). To our knowledge, there have been no studies 
published that elucidate the biology of $m i R-17-5 p$ and $m i R-20 a$ in human colorectal cancer.

Recently, miR-200c (39) and miR-21 (26) expression were reported to be associated with poor survival in colorectal cancer patients. In this study, we demonstrated that the $m i R$ $18 a$ high expression group tended to have a poorer prognosis than the low expression group ( $\mathrm{P}=0.07$ : Fig. 3 ) and we believe that $m i R-18 a$ expression can be used as a prognostic factor in predicting survival of postoperative colorectal cancer patients.

The expression of $m i R-143$ and $m i R-145$ are downregulated in colorectal tumors and their in vitro transfection into human colon cancer cell lines (DLD-1, SW480) led to growth inhibition $(21,22,25)$. In our study, real-time RT-PCR analysis showed that expression of $m i R-143$ and $m i R-145$ were significantly lower in 43 and 44 clinical colorectal cancers, respectively, than in normal tissues $(\mathrm{P}<0.05$ : Fig. 2$)$.

In conclusion, this study identified 21 up-regulated miRNAs in human colorectal cancers. MiR-31, miR-183, $m i R-18 a, m i R-17-5 p, m i R-20 a$ and $m i R-92$ were significantly overexpressed in cancer compared to normal tissues. The advent of miRNA research may lead to possible applications to molecular diagnostics and prognostics in colorectal cancer. More study is required to clarify the precise contributions of miRNAs to colorectal cancer progression.

\section{Acknowledgements}

We thank K. Minoura (Agilent Technologies Japan, Ltd.), T. Shimooka, K. Ogata, M. Kasagi and Y. Nakagawa for excellent technical assistance and advice. Grant support: Core Research for Evolutional Science and Technology (CREST), Japan Science and Technology Agency (JST); Grants-in-aid for scientific research, grant numbers $17109013,18390367,18590333,18659384,18890133$, 18015039, 19390336, and 19591509.

\section{References}

1. Lagos-Quintana M, Rauhut R, Lendeckel W and Tuschl T: Identification of novel genes coding for small expressed RNAs. Science 294: 853-858, 2001.

2. Lee $\mathrm{Y}$, Jeon K, Lee JT, Kim S and Kim VN: MicroRNA maturation: stepwise processing and subcellular localization. EMBO J 21: 4663-4670, 2002.

3. Lee Y, Ahn C, Han J, et al: The nuclear RNase III Drosha initiates microRNA processing. Nature 425: 415-419, 2003.

4. Lund E, Guttinger S, Calado A, Dahlberg JE and Kutay U: Nuclear export of microRNA precursors. Science 303: 95-98, 2004.

5. Ambros V: The functions of animal microRNAs. Nature 431: 350-355, 2004.

6. Bartel DP: MicroRNAs: genomics, biogenesis, mechanism, and function. Cell 116: 281-297, 2004.

7. Filipowicz W: RNAi: the nuts and bolts of the RISC machine Cell 122: 17-20. 2005

8. Lim LP, Lau NC, Garrett-Engele P, et al: Microarray analysis shows that some microRNAs downregulate large numbers of target mRNAs. Nature 433: 769-773, 2005.

9. Carthew RW: Gene regulation by microRNAs. Curr Opin Genet Dev 16: 203-208, 2006

10. Berezikov E, Guryev V, van de Belt J, Wienholds E, Plasterk RH and Cuppen E: Phylogenetic shadowing and computational identification of human microRNA genes. Cell 120: 21-24, 2005.

11. Lewis BP, Burge CB and Bartel DP: Conserved seed pairing, often flanked by adenosines, indicates that thousands of human genes are microRNA targets. Cell 120: 15-20, 2005.
12. Hwang HW and Mendell JT: MicroRNAs in cell proliferation, cell death, and tumorigenesis. Br J Cancer 94: 776-780, 2006

13. Calin GA, Sevignani C, Dumitru CD, et al: Human microRNA genes are frequently located at fragile sites and genomic regions involved in cancers. Proc Natl Acad Sci USA 101: 2999-3004, 2004.

14. Cho WC: OncomiRs: the discovery and progress of microRNAs in cancers. Mol Cancer 6: 60, 2007

15. Esquela-Kerscher A and Slack FJ: Oncomirs - microRNAs with a role in cancer. Nat Rev Cancer 6: 259-269, 2006.

16. Hammond SM: MicroRNAs as oncogenes. Curr Opin Genet Dev 16: 4-9, 2006

17. Kumar MS, Lu J, Mercer KL, Golub TR and Jacks T: Impaired microRNA processing enhances cellular transformation and tumorigenesis. Nat Genet 39: 673-677, 2007.

18. Fabbri M, Croce CM and Calin GA: MicroRNAs. Cancer J 14: $1-6,2008$.

19. Gartel AL and Kandel ES: miRNAs: Little known mediators of oncogenesis. Semin Cancer Biol 18: 103-110, 2008

20. Croce CM: Oncogenes and cancer. N Engl J Med 358: 502-511, 2008.

21. Michael MZ, O'Connor SM, van Holst Pellekaan NG, Young GP and James RJ: Reduced accumulation of specific microRNAs in colorectal neoplasia. Mol Cancer Res 1: 882-891, 2003.

22. Akao Y, Nakagawa Y and Naoe T: MicroRNAs 143 and 145 are possible common onco-microRNAs in human cancers. Oncol Rep 16: 845-850, 2006.

23. Volinia S, Calin GA, Liu CG, et al: A microRNA expression signature of human solid tumors defines cancer gene targets. Proc Natl Acad Sci USA 103: 2257-2261, 2006.

24. Bandres E, Cubedo E, Agirre X, et al: Identification by real-time PCR of 13 mature microRNAs differentially expressed in colorectal cancer and non-tumoral tissues. Mol Cancer 5: 29, 2006.

25. Akao Y, Nakagawa Y and Naoe T: MicroRNA-143 and -145 in colon cancer. DNA Cell Biol 26: 311-320, 2007

26. Schetter AJ, Leung SY, Sohn JJ, et al: MicroRNA expression profiles associated with prognosis and therapeutic outcome in colon adenocarcinoma. JAMA 299: 425-436, 2008.

27. Wang H, Ach RA and Curry B: Direct and sensitive miRNA profiling from low-input total RNA. RNA 13: 151-159, 2007.

28. Talbot IC, Ritchie S, Leighton MH, Hughes AO, Bussey HJ and Morson BC: The clinical significance of invasion of veins by rectal cancer. Br J Surg 67: 439-442, 1980

29. Slaby O, Svoboda M, Fabian P, et al: Altered expression of miR-21, miR-31, miR-143 and miR-145 is related to clinicopathologic features of colorectal cancer. Oncology 72 : 397-402, 2008.

30. Kent OA and Mendell JT: A small piece in the cancer puzzle: microRNAs as tumor suppressors and oncogenes. Oncogene 25: 6188-6196, 2006

31. He L, Thomson JM, Hemann MT, et al: A microRNA polycistron as a potential human oncogene. Nature 435: 828-833, 2005.

32. Hayashita Y, Osada H, Tatematsu Y, et al: A polycistronic microRNA cluster, miR-17-92, is overexpressed in human lung cancers and enhances cell proliferation. Cancer Res 65: 9628-9632, 2005

33. Dews M, Homayouni A, Yu D, et al: Augmentation of tumor angiogenesis by a Myc-activated microRNA cluster. Nat Genet 38: 1060-1065, 2006.

34. O'Donnell KA, Wentzel EA, Zeller KI, Dang CV and Mendell JT: c-Myc-regulated microRNAs modulate E2F1 expression. Nature 435: 839-843, 2005.

35. Sylvestre Y, De Guire V, Querido E, et al: An E2F/miR-20a autoregulatory feedback loop. J Biol Chem 282: 2135-2143, 2007.

36. Woods K, Thomson JM and Hammond SM: Direct regulation of an oncogenic micro-RNA cluster by E2F transcription factors. J Biol Chem 282: 2130-2134, 2007

37. Ventura A, Young AG, Winslow MM, et al: Targeted deletion reveals essential and overlapping functions of the miR-17 through 92 family of miRNA clusters. Cell 132: 875-886, 2008.

38. Matsubara H, Takeuchi T, Nishikawa E, et al: Apoptosis induction by antisense oligonucleotides against miR-17-5p and miR-20a in lung cancers overexpressing miR-17-92. Oncogene 26: 6099-6105, 2007.

39. Xi Y, Formentini A, Chien M, et al: Prognostic Values of microRNAs in colorectal cancer. Biomark Insights 2: 113-121, 2006. 